\title{
Tensile bond strength of adhesive systems - effects of primer and thermocycling
}

\section{Resistência à tração de sistemas adesivos - efeitos do "primer" e dos ciclos térmicos}

\author{
Luciana Tibiriçá AGUILAR* \\ Nathalie Pepe Medeiros REZENDE* \\ Alessandra REIS* \\ Alessandro Dourado LOGUERCIO* \\ Rosa Helena Miranda GRANDE** \\ Rafael Yagüe BALLESTER** \\ Julio da Motta SINGER ${ }^{* * *}$
}

\begin{abstract}
AGUILAR, L. T.; REZENDE, N. P. M.; REIS, A.; LOGUERCIO, A. D.; GRANDE, R. H. M.; BALLESTER, R. Y.; SINGER, J. da M. Tensile bond strength of adhesive systems - effects of primer and thermocycling. Pesqui Odontol Bras, v. 16, n. 1 , p. 37-42, jan./mar. 2002.
\end{abstract}

\begin{abstract}
The objective of this study was to evaluate the effects of primer and thermocycling on the bond strength of multi-purpose adhesive systems applied to enamel, under tensile stress. The following bonding systems were applied, according to the manufacturers' instructions, on unground enamel buccal surfaces of 96 premolars, with or without the application of primer: Scotchbond MP, OptiBond FL, Amalgambond Plus and OptiBond (dual-cure). A composite resin (Z100, $3 \mathrm{M})$ was applied and light-cured in a cast metal hollow cone, which was previously fixed to the enamel surfaces. Half of the sample was subjected to 3,000 thermocycles $\left(5-37^{\circ} \mathrm{C} ; 37-55^{\circ} \mathrm{C}\right.$, dwell time of $\left.60 \mathrm{~s}\right)$, and the other half was stored in water at $37^{\circ} \mathrm{C}$ for the same period. The data were treated by means of ANOVA and no significant effects were detected, which indicates that tensile bond strength was not affected by the adhesive systems, application of primer or thermocycling.
\end{abstract}

UNITERMS: Dentin-bonding agents; Dental enamel; Tensile strength; Materials testing.

\section{INTRODUCTION}

The acid etching technique introduced by BUONOCORE $^{3}$ (1955) has led to great changes in the practice of dentistry due to the development of adhesive systems. Moreover, these systems have improved esthetics and marginal adaptation of restorative materials, which reduced microleakage and allowed for the confection of long-term restorations ${ }^{24}$.

Higher values of bond strength to enamel can be obtained by acid-etching the surface. The adhesion to the enamel substrate relies on micro-mechanical retention which is assumed to be a function of increased microporosity and high surface energy - these factors improve the superficial wettability for bonding agents and lead to the formation of tag-like extensions within the enamel ${ }^{6}$.
Nevertheless, because of the heterogeneous morphology and the dynamic physiology of dentin, with its inherited wetness, several generations of adhesive systems were developed to improve bonding to that stucture. A reliable adhesion to dentin was obtained only with the development of hydrophilic monomers and with the introduction of a primer solution that is utilized prior to the application of the adhesive resin. The primer solution is a combination of hydrophilic monomers and solvents whose function is to carry resin monomers into the collagen network, previously exposed by acid conditioning, at the same time that it displaces moisture from the dentin surface via solvents; this creates a resin-reinforced layer known as hybrid layer ${ }^{19}$.

Bonding to enamel was well established before the development of these multi-step adhesive

*Graduate Students; **PhD, Department of Dental Materials - School of Dentistry, University of São Paulo.

${ }^{* * *}$ Chairman, Department of Statistics, Institute of Mathematics and Statistics, University of São Paulo. 
AGUILAR, L. T.; REZENDE, N. P. M.; REIS, A.; LOGUERCIO, A. D.; GRANDE, R. H. M.; BALLESTER, R. Y.; SINGER, J. da M. Tensile bond strength of adhesive systems - effects of primer and thermocycling. Pesqui Odontol Bras, v. 16, n. 1, p. 37-42, jan./mar. 2002.

systems. Considering that enamel is basically composed by inorganic material, with practically no water content, the application of a primer solution on its surface seems unnecessary. However, it is almost impossible to apply the primer solution only on dentin when treating cavities involving both enamel and dentin. Concerns about the effect of primer on the adhesion to enamel were raised and several studies have shown controversial results regarding its use before the application of the bonding resin ${ }^{1,7,23,26}$.

On the other hand, a common practice in some laboratorial studies, such as in the evaluation of gaps and microleakage, is to subject the specimens to rather severe thermal stress in short periods of time in order to mimic an accelerated aging test. The ability of this methodology to predict the failure of the interface is controversial ${ }^{4,9,18}$, and few studies have evaluated its effect on tensile bond strength.

Therefore, our objective was to evaluate the effects of the application of primer, as well as the effects of thermocycling processes, on bond strength, under tensile test.

\section{MATERIAL AND METHODS}

Ninety-six non-carious human premolars, extracted for orthodontic reasons and cleaned from debris, were stored for 15 days in a $10 \%$ formalin solution. Then, the teeth were embedded in acrylic resin so that the buccal surface was left exposed. The unground buccal enamel was pumiced and the specimens were stored in distilled water.

The sample was randomly divided into 16 groups (with 6 teeth each) comprising all combinations of the factors under investigation, namely, adhesive system, primer and thermal stress (Figure 1).

Four three-step total-etch adhesive systems were evaluated in this study. The materials and their compositions are described in Table 1 . The buccal surface of each tooth was etched according to the manufacturers' instructions. They were rinsed off for $15 \mathrm{~s}$ and air-dried for $15 \mathrm{~s}$. Half of the

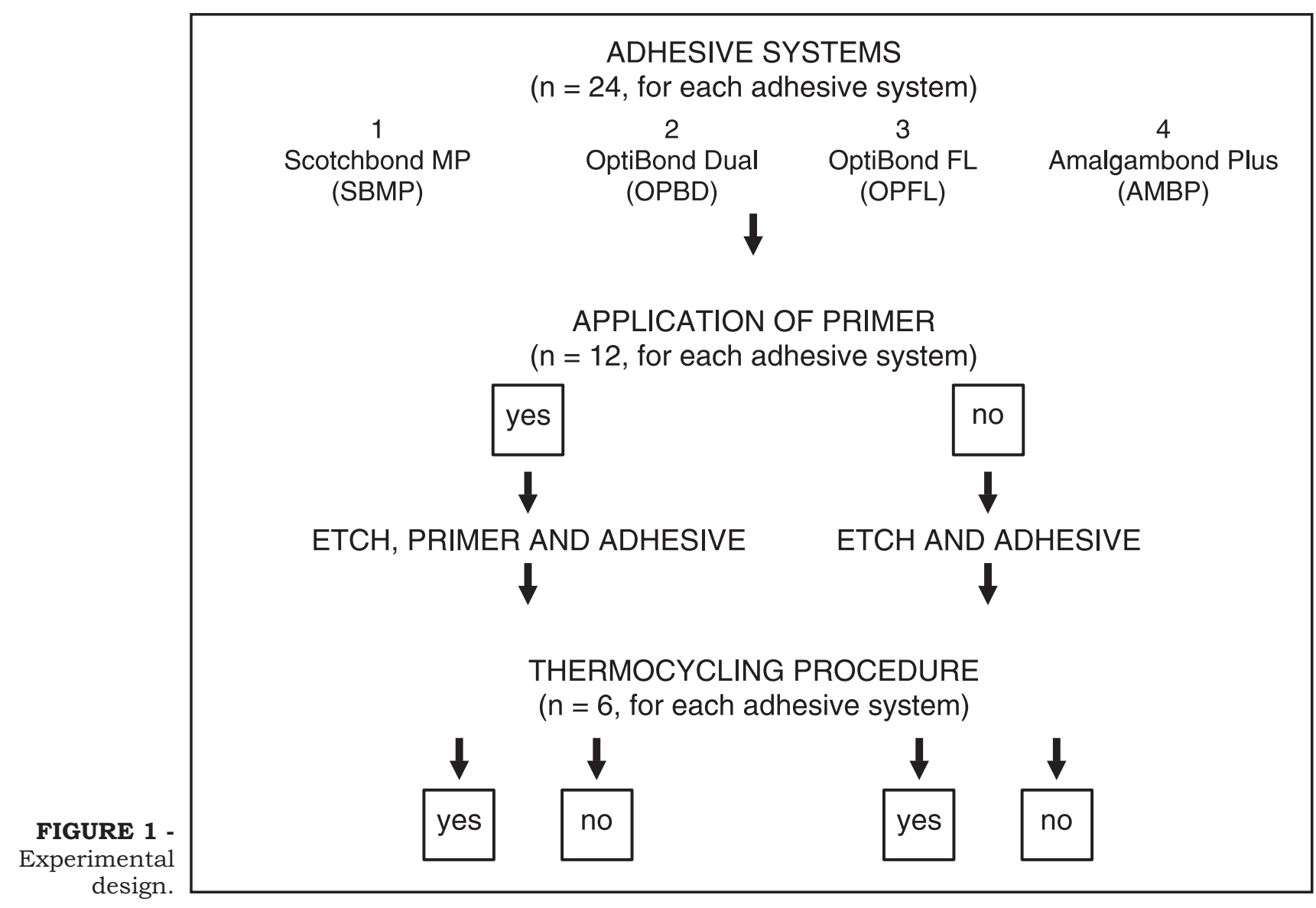


AGUILAR, L. T.; REZENDE, N. P. M.; REIS, A.; LOGUERCIO, A. D.; GRANDE, R. H. M.; BALlESTER, R. Y.; SINGER, J. da M. Tensile bond strength of adhesive systems - effects of primer and thermocycling. Pesqui Odontol Bras, v. 16, n. 1, p. 37-42, jan./mar. 2002.

sample was treated with primer plus and received the adhesive resin, whereas on the other half, only the adhesive resin was applied.

The smaller orifice $\left(3 \mathrm{~mm}^{2}\right)$ of a 4 -mm-high inverted hollow $\mathrm{Ni}-\mathrm{Cr}$ cone was placed against the enamel surfaces in order to receive the filling material (Figure 2). The composite resin was placed in 3 increments, light-cured for $40 \mathrm{~s}$ each, by means of an Optilux 500 (Demetron) unit with a light output of $600 \mathrm{~mW} / \mathrm{cm}^{2}$.

Half of the sample of each adhesive system was subjected to 3,000 thermal cycles $\left(55^{\circ} \mathrm{C}-37^{\circ} \mathrm{C}\right.$ and $37^{\circ} \mathrm{C}-55^{\circ} \mathrm{C}$, dwell time of $\left.60 \mathrm{~s}\right)$. The other half was

TABLE 1 - Adhesive systems and their compositions.

\begin{tabular}{c|l}
\hline $\begin{array}{c}\text { Adhesive } \\
\text { system }\end{array}$ & \multicolumn{1}{c}{ Composition } \\
\hline SBMP & $\begin{array}{l}\text { 1. Acid - 35\% phosphoric acid } \\
\text { 2. Primer - HEMA, polycarboxylic acid and water } \\
\text { 3. Adhesive - Bis-GMA, HEMA and hexafluor- } \\
\text { phosphate }\end{array}$ \\
\hline OPBD & $\begin{array}{l}\text { 1. Acid - 38\% phosphoric acid } \\
\text { 2. Primer - HEMA, GPDM, PMMA, water and } \\
\text { 3. Dual-cure A - Bis-GMA and HEMA } \\
\text { 4. Dual-cure B - HEMA, GBPD and filler (48\%) }\end{array}$ \\
\hline OPFL & $\begin{array}{l}\text { 1. Acid - 38\% phosphoric acid } \\
\text { 2. Primer - HEMA, GPDM, PMMA, water and } \\
\text { ethanol } \\
\text { 3. Adhesive - Bis-GMA, HEMA, GDMA and } \\
\text { filler (48\%) }\end{array}$ \\
\hline AMBP & $\begin{array}{l}\text { 1. 10\% citric acid and 3\% ferric chloride } \\
\text { 2. Primer - 35\% HEMA and water } \\
\text { 3. Adhesive - 4-META, MMA and TBB }\end{array}$ \\
\hline \hline
\end{tabular}

SBMP = Scotchbond MP; OPBD = OptiBond (dual-cure); OPFL $=$ OptiBond FL; AMBP $=$ Amalgambond Plus .

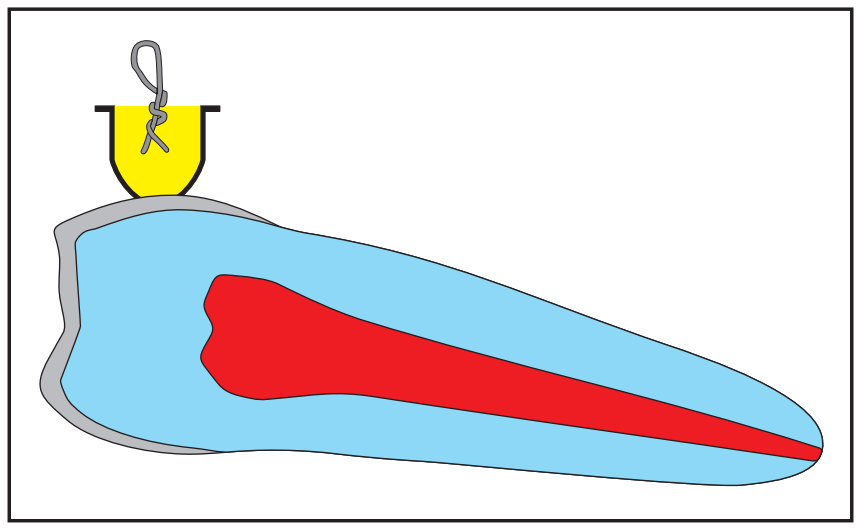

FIGURE 2 - Schematic illustration of the specimen. kept in distilled water at a $37^{\circ} \mathrm{C}$ during the same period.

A standard device was utilized to fix the specimens on an E2R-30 Wolpert machine, in order to guarantee only axial tensile stress. The test was carried out with an increasing load of $0.1 \mathrm{kp} / \mathrm{min}$ up to debonding.

A three-way ANOVA ${ }^{20}$ method $(p=0.05)$ was employed to evaluate the effects of the factors under investigation.

\section{RESULTS}

The average bond strength values and standard deviation (SD) observed in each group are shown in Table 2, and the results of the ANOVA, in Table 3 . The results suggest that neither the interactions nor the main factors were statistically significant. The global mean bond strength value $(9.92 \pm$ $5.5 \mathrm{MPa}$ ) was similar for the adhesive systems, with or without the application of primer, subjected or not to thermocycling. In order to better comply with the ANOVA assumptions, additional analyses with transformed variables (variance stabilizing) were carried out, but the results remained unaltered.

\section{DISCUSSION}

None of the studied factors influenced the tensile bond strength of the three-step adhesive systems applied on enamel. This result does not completely agree with those of other published studies.

HOTTA et al. ${ }^{11}$ (1992) demonstrated that the mixture of hydrophilic 4-MET with hydrophobic monomer produced an increase in bond strength to enamel due to a better encapsulation of the crystallite in the outer enamel. Other authors advocated that the application of a primer solution (hydrophilic monomers plus solvents) on enamel could adversely affect the adhesion to that structure. MIYAZAKI et al. ${ }^{16}$ (1996) conjectured that the lower bond strength to enamel, obtained after the application of primer, was due to incomplete evaporation of the solvent from the primer solution. Corroborating that, HOTTA et al. ${ }^{12}$ (1998) observed that mixtures of adhesives/primers containing higher amounts of primer yielded a lower degree of conversion and inferior mechanical properties when compared with mixtures containing a lower proportion of primer. According to these authors, the primer content could inhibit the polymerizati- 
AGUILAR, L. T.; REZENDE, N. P. M.; REIS, A.; LOGUERCIO, A. D.; GRANDE, R. H. M.; BALLESTER, R. Y.; SINGER, J. da M. Tensile bond strength of adhesive systems - effects of primer and thermocycling. Pesqui Odontol Bras, v. 16, n. 1, p. 37-42, jan./mar. 2002.

TABLE 2 - Average tensile bond strength and standard deviation (MPa).

\begin{tabular}{c|c|c|c|c}
\hline \hline \multirow{2}{*}{ Adhesives } & \multicolumn{2}{|c|}{ With primer } & \multicolumn{2}{c}{ Without primer } \\
\cline { 2 - 5 } & With thermocycling & Without thermocycling & With thermocycling & Without thermocycling \\
\hline AMBP & $11.36 \pm 8.74$ & $9.63 \pm 4.67$ & $7.77 \pm 4.11$ & $10.35 \pm 4.46$ \\
\hline OPBD & $8.25 \pm 4.91$ & $12.18 \pm 6.73$ & $13.53 \pm 6.91$ & $12.05 \pm 4.52$ \\
\hline SBMP & $5.9 \pm 5.07$ & $9.87 \pm 4.45$ & $9.95 \pm 3.35$ & $9.05 \pm 3.25$ \\
\hline OBFL & $9.31 \pm 5.80$ & $8.04 \pm 5.22$ & $12.78 \pm 7.44$ & $9.15 \pm 4.18$ \\
\hline \hline
\end{tabular}

AMBP = Amalgambond Plus; OPBD = OptiBond (dual-cure); SBMP = Scotchbond MP; OPFL = OptiBond FL.

TABLE 3 - Three-way ANOVA.

\begin{tabular}{l|r|r|c|c|c}
\hline \hline Source of variation & DF & SS & MS & F & $\mathrm{p}$ \\
\hline Adhesive (A) & 3 & 103.26 & 34.421 & 1.16 & 0.329 \\
\hline Primer (P) & 1 & 41.40 & 41.40 & 1.40 & 0.240 \\
\hline Thermocycling (T) & 1 & 1.30 & 1.30 & 0.04 & 0.834 \\
\hline A x P & 3 & 62.8 & 20.69 & 0.74 & 0.555 \\
\hline A x T & 3 & 62.84 & 20.95 & 0.71 & 0.550 \\
\hline P x T & 1 & 28.73 & 28.73 & 0.97 & 0.327 \\
\hline A x P x T & 3 & 93.21 & 31.07 & 1.05 & 0.375 \\
\hline Error & 80 & $2,367.74$ & 29.60 & - & - \\
\hline \hline
\end{tabular}

$\mathrm{DF}=$ degree of freedom; $\mathrm{SS}=$ sum of squares; $\mathrm{MS}=$ mean of squares.

on of free radicals and adversely affect the mechanical properties of the adhesive resin.

Other studies considered that the primer might act as a contaminator agent, like saliva or water. According to those studies, the presence of primer on conditioned enamel modifies the pattern of tag formation, reducing the number and size of microporosities $^{1}$, which lead to lower bond strength values $^{1,7,23}$. However, it must be pointed out that these low bond strength values were obtained with previous generations of adhesive systems, which contained exclusively hydrophobic monomers.

In opposition to such observations, the findings of this study demonstrated that the presence of primer does not play any detrimental effect on bonding to enamel. Results from other studies, which tested total etch adhesive systems, are in agreement with the results of this study - no interference of the primer contents was observed on adhesion to enamel ${ }^{26}$. A recent study published by JAIN; STEWART ${ }^{15}$ (2000) demonstrated results si- milar to those of our study when adhesives were applied on dry etched enamel. Although all tested materials belonged to the same category - total-etch adhesive systems -, some differences related to etching conditioners, modes of activation, monomers, solvents, inclusion of inorganic fillers and other variables could have masked the influence of the other studied factors, which justifies the similar results of the tested groups.

Apart from that, the enamel surfaces were not ground and flattened before the application of adhesives in order to simulate a clinical situation. This is not a common practice among the studies that employ tensile and shear bond strength tests ${ }^{2,8}$ and it could also have contributed to the similarity of the bond strength results.

Considering dry etched enamel contaminated with saliva or water, the primer solutions may even play an important role on adhesion. Recent studies have suggested that the etched enamel is less sensitive to contamination when new generations of adhesive resins are used ${ }^{5,13,25}$. The "water chasing" ability of primer solutions may provide a beneficial effect on adhesion to enamel by reducing the water content on the contaminated enamel surface, as demonstrated by JAIN; STEWART ${ }^{15}$ (2000).

The total-etching adhesive systems utilized in this study are also called three-step systems because the conditioner, primer and bonding agents are purchased in separate bottles. In an effort to simplify the bonding procedures, several new adhesive systems rely on etching the enamel and dentin with acids and applying single-bottle adhesives that combine the functions of primer and bonding agent. These systems require the application of the primer/adhesive solution on both dentin and enamel - no detrimental effect on bond strength to enamel has been reported ${ }^{8,22}$. 
AGUILAR, L. T.; REZENDE, N. P. M.; REIS, A.; LOGUERCIO, A. D.; GRANDE, R. H. M.; BALlESTER, R. Y.; SINGER, J. da M. Tensile bond strength of adhesive systems - effects of primer and thermocycling. Pesqui Odontol Bras, v. 16, n. 1, p. 37-42, jan./mar. 2002 .

It is difficult to predict, based on data obtained in laboratorial tests, the clinical longevity of an adhesive system. Therefore, longer periods of storage of the bonded specimens in water and/or thermocycling might give some information about the degradation of the material. ISO TR $11450^{14}$ (1994) indicates that the thermocycling test comprising 500 cycles in water at $5^{\circ}$ and $55^{\circ} \mathrm{C}$ might be used as an accelerated aging test. The majority of the studies that use this methodology are related to dentin bond strength testing and they present different results. XIROUCHAKI et al. ${ }^{27}$ (1997), after evaluating, on dentinal surfaces, the effect of 2,500 cycles on the bond strength of newly developed systems, concluded that thermocycling did not significantly affect bond strength. In this study, no differences were observed in bond strength values after 3,000 cycles. MIYAZAKI et al. ${ }^{17}$ (1998) observed a decrease in bond strength values only after 30,000 cycles.

Although some authors did not detect significant differences between specimens subjected or not to thermocycling ${ }^{4,9}$, other authors observed its efficacy in developing debonding areas only after a high number of cycles ${ }^{10,18}$. This confirms the controversial results on this matter.

This study suggests that the most important factor in accelerating the aging process may be the deleterious effect of immersion in water, since neither thermocycled nor stored specimens presented significant differences when tensile bond tests were performed. According to PERDIGÃO ${ }^{21}$ (1995), the absorption of water during thermocycling or storage may counterbalance the contraction caused by the polymerization of resin, reducing the development of stress, which would lead to the failure of adhesion.

\section{CONCLUSIONS}

Neither the application of primer on dry etched enamel nor the utilization of thermocycling processes caused detrimental effects on the tensile bond strength of adhesive systems applied on enamel.

\section{ACKNOLEDGMENTS}

The authors are grateful to José Airton de Oliveira for technical assistance.

This study was partially supported by FAPESP (96/05748-6 and 96/62216-8) and CAPES.

AGUILAR, L. T.; REZENDE, N. P. M.; REIS, A.; LOGUERCIO, A. D.; GRANDE, R. H. M.; BALLESTER, R. Y.; SINGER, J. da M. Resistência à tração de sistemas adesivos - efeitos do "primer" e dos ciclos térmicos. Pesqui Odontol Bras, v. 16 , n. 1, p. 37-42, jan./mar. 2002.

O objetivo desta pesquisa foi o de verificar o efeito do "primer" e dos ciclos térmicos na resistência da união entre adesivos multiuso e esmalte dental, sob ensaios de tração. Os seguintes sistemas adesivos foram aplicados, de acordo com as instruções dos fabricantes, na superfície vestibular (sem desgaste) de 96 pré-molares com ou sem a aplicação prévia do "primer": Scotchbond MP, OptiBond FL, Amalgambond Plus e OptiBond - "dual cure". Após a aplicação do sistema adesivo, foi confeccionado um cone de resina composta $(\mathrm{Z} 100,3 \mathrm{M})$, e fotoativado dentro de um molde metálico. Metade do total de espécimes foi submetida a 3.000 ciclos térmicos $\left(5-37^{\circ} \mathrm{C} ; 37-55^{\circ} \mathrm{C}, 60 \mathrm{~s}\right.$ de imersão); a outra metade permaneceu imersa em água a $37^{\circ} \mathrm{C}$ pelo mesmo tempo dispensado no procedimento anterior. Os dados foram submetidos a uma análise de variância $(\mathrm{p}=0,05)$ e nenhum efeito significante foi detectado, indicando que a resistência de união não foi afetada pelo sistema adesivo, pela aplicação do "primer" ou pelos ciclos térmicos.

UNITERMOS: Adesivos dentinários; Esmalte dentário; Resistência à tração; Teste de materiais.

\section{BIBLIOGRAPHIC REFERENCES}

1. BARKMEIER, W. W.; GWINNETT, A. J. A scanning electron microscopy study of dentin and enamel surfaces treated with three new resin adhesive systems. Compend Contin Educ Dent, v. 10, n. 3, p. 145-146, 148-149, 152-153, Mar. 1989.

2. BENDERLI, Y.; GOKCE, K.; BUYUKGOKCESU, S. In vitro shear bond strength of adhesive to normal and fluoridated enamel under various contaminated conditions. Quintessence Int, v. 30, n. 8, p. 570-575, Aug. 1999.
3. BUONOCORE, M. G. A simple method of increasing the adhesion of acrylic filling materials to enamel surfaces. $\mathbf{J}$ Dent Res, v. 34, n. 6, p. 849-853, Dec. 1955.

4. EAKLE, W. S. Effect of thermal cycling on fracture strength and microleakage in teeth restored with a bonded composite resin. Dent Mater, v. 2, n. 3, p. 14-17, June 1986.

5. EL-KALLA, I. H.; GARCIA-GODOY, F. Saliva contamination and bond strength of single-bottle adhesives to enamel and dentin. Am J Dent, v. 10, n. 2, p. 83-87, Apr. 1997. 
AGUILAR, L. T.; REZENDE, N. P. M.; REIS, A.; LOGUERCIO, A. D.; GRANDE, R. H. M.; BALLESTER, R. Y.; SINGER, J. da M. Tensile bond strength of adhesive systems - effects of primer and thermocycling. Pesqui Odontol Bras, v. 16, n. 1, p. 37-42, jan./mar. 2002 .

6. GWINNETT, A. J.; MATSUI, A. A study of enamel adhesives. The physical relationship between enamel and adhesive. Arch Oral Biol, v. 12, n. 12, p. 1615-1620, Dec. 1967.

7. HADAVI, F.; HEY, J. H.; AMBROSE, E. R. et al. The effect of dentin primer on the shear bond strength between composite resin and enamel. Oper Dent, v. 18, n. 2, p. 61-65, Mar./Apr. 1993.

8. HARA, A. T.; AMARAL, C. M.; PIMENTA, L. A.; SINHORETI, M. A. Shear bond strength of hydrophilic adhesive systems to enamel. Am J Dent, v. 12, n. 4, p. 181-184, Aug. 1999.

9. HASEGAWA, T.; RETIEF, H.; RUSSEL, C. M.; DENYS, F. R. Shear bond strength and quantitative microleakage of a multipurpose dental adhesive system resin bonded to dentin. J Prosthet Dent, v. 73, n. 5, p. 432-438, May 1995.

10. HOSOYA, Y. Resin adhesion to the ground young permanent enamel: influence of etching times and thermocycling test. J Clin Pediatr Dent, v. 18, n. 2, p. 115-122, Winter 1994.

11. HOTTA, K.; MOGI, M.; MIURA, F.; NAKABAYASHI, N. Effect of 4-MET on bond strength and penetration of monomers into enamel. Dent Mater, v. 8, n. 3, p. 173-175, May 1992.

12. HOTTA, M.; KONDOH, K.; KARNEMIZU, H. Effect of primers on bonding agent polymerization. J Oral Rehabil, v. 25, n. 10, p. 792-799, Oct. 1998.

13. IWAMI, Y.; YAMAMOTO, H.; KAWAI, K.; EBISU, S. Effect of enamel and dentin surface wetness on shear bond strength of composites. J Prosthet Dent, v. 80, n. 1, p. 20-26, July 1998.

14. INTERNATIONAL ORGANIZATION FOR STANDARDIZATION. Dental materials - guidance on testing of adhesion to tooth structure. Switzerland: ISO, 1994. 15 p. [Reference number ISO TR 11405:1994].

15. JAIN, P.; STEWART, G. P. Effect of dentin primer on shear bond strength of composite resin to moist and dry enamel. Oper Dent, v. 25, n. 1, p. 51-58, Jan./Feb. 2000.

16. MIYAZAKI, M.; PLATT, J. A.; ONOSE, H.; MOORE, B. K. Influence of dentin primer application methods on den- tin bond strength. Oper Dent, v. 21, n. 4, p. 167-172, July/Aug. 1996.

17. MIYAZAKI, M.; SATO, M.; ONOSE, H.; MOORE, B. K. Influence of thermal cycling on dentin bond strength of two-step bonding systems. Am J Dent, v. 11, n. 3, p. 118-122, June 1998 .

18. MOMOI, Y.; IWASE, H.; NAKANO, Y. et al. Gradual increase in marginal leakage of resin composite restorations with thermal stress. J Dent Res, v. 69, n. 10, p. 1659-1663, Oct. 1990.

19. NAKABAYASHI, N.; WATANABE, A.; GENDUSA, N. J. Dentin adhesion of "modified" 4-META/MMA-TBB resin: function of HEMA. Dent Mat J, v. 8, n. 4, p. 259-264, July 1992.

20. NETER, J.; KUTNER, M. H.; NACHTSHEIM, C. J.; WASSERMAN, W. Applied linear statistical models. Homewood : Irwin, 1996. p. 1408.

21. PERDIGÃO, J. An ultra-morphological study of human dentine exposed to adhesive systems. 1995. $132 \mathrm{p}$. Thesis (Doctor in Medical Sciences) - Catholic University of Leuven, Leuven.

22. SWIFT, E. J.; PERDIGÃO, J.; HEYMANN, H. O.; RITTER, A. $\mathrm{V}$. Shear bond strengths of one-bottle adhesives to moist enamel. J Esthet Dent, v. 11, n. 2, p. 103-107, 1999.

23. THOMS, L. M.; NICHOLLS, J. L.; BRUDVIK, J. S.; KYDD, W. L. The effect of dentin primer on the tensile bond strength to human enamel. Int J Prosthodont, v. 7, n. 5, p. 403-409, Sept./Oct. 1994.

24. Clinical status of ten dentin adhesive systems. J Dent Res, v. 73, n. 11, p. 1690-1702, Nov. 1994.

25. WITZEL, M. F.; GRANDE, R. H. M.; SINGER, J. M. Bonding systems used for sealing: evaluation of microleakage. $\mathbf{J}$ Clin Dent, v. 11, n. 2, p. 47-52, 2000.

26. WORONKO Jr., G. A.; SAINT GERMAIN Jr., H. A.; MEIERS, J. C. Effect of dentin primer on the shear bond strength between composite resin and enamel. Oper Dent, v. 21, n. 3, p. 116-121, May/June 1996.

27. XIROUCHAKI, A.; MOORE, B. K.; COCHRAN, M. A. Shear bond strength of 6 new dentin bond agents. J Dent Res, v. 76, p. 227, 1997. [Abstract n. 2110].

Recebido para publicação em 09/05/01

Enviado para reformulação em 27/08/01

Aceito para publicação em 05/10/01 